Schmidt M. (2012): Changing human-environment interrelationships in

Kyrgyzstan's walnut-fruit forests. In: Forests, Trees and Livelihoods 21(4), 253-266.

DOI:http://dx.doi.org/10.1080/14728028.2012.755811

\title{
Changing human-environment interrelationships in Kyrgyzstan's walnut-fruit forests
}

\author{
Matthias Schmidt
}

Human-environment relationships and natural resource management are embedded in political and institutional regimes. Thus, political and socio-economic transitions often lead to remarkable changes in the interrelationships between forests, people and livelihoods. Post-Soviet Kyrgyzstan has been shaped by several comprehensive system transformations; consequently the interpretation, utilisation and management of its scarce forest resources have changed significantly. Kyrgyzstan's globally unique walnut-fruit forests are esteemed for their vital role in controlling erosion and balancing the water cycle, for delivering forestry goods such as timber, nuts and fruits, as a genetic pool and for their recreational functions. The value of the forests was perceived already under Russian colonial rule, resulting in the establishment of specific management and protection regulations. During the Soviet era, the forests were handled accordingly in a strict topdown approach, with local people involved only in carrying out orders to fulfil plans drawn by superior bureaucrats. Political and socio-economic transformations after 1991 require modifications of livelihoods in which the forests play a major role. Economic liberalisations not only offer chances for income generation but also threaten the very existence of the forests: extensive pasturing, firewood extraction and illegal timber cutting lead to degradation. Based on a political ecology approach, the paper explores the changing interrelationships betweenKyrgyzstan's walnut-fruit forests and local societies.

Keywords: human-environment relationships; forest use history; natural resource management; political ecology; post-Soviet transformation; Central Asia

\section{Introduction}

Forests are a scarce but valuable occurrence in Central Asia and thus play a crucial role for local societies. This is particularly true for the unique walnut-fruit forests of the Fergana Range in the Western Tian Shan (Kyrgyzstan) (Beyeler et al. 2011; Figure 1). These forests cover an area of around 40,000 ha at elevations between 1000 and $2000 \mathrm{~m}$ and contain a large variety of woody species such as walnut (Juglans regia) and maple (Acerturkestanica), as well as various fruit-bearing species in their wild form: apple (Malussieversii), pear (Pyrus korshinskyi), plum (Prunus sogdiana), barberry (Berberis oblonga) and others (Gottschling et al. 2005; Venglovsky et al. 2010). However, natural entities such as forest lands, trees or fruits are appreciated as resources only because of human demand (Bridge 2009).Humans attribute value to themand articulate concerns about specific functions and products for various aims that change over time. When human-environment relationships or discourses about natural resources are being analysed, historical and political particularities have to be taken into consideration. This is notably true for studies in post-Soviet Central Asia, a region that has been shaped by several far-reaching political and socio-economic transformations (Allworth 1994; Luong 2004). Ruled for centuries by feudal Khans, Central Asia was conquered by Tsarist Russia in the nineteenth century and later became a part of the Soviet Union till its disintegration in 1991 (Allworth 1994; Adle et al. 2005). In other words, Tsarist colonialism, Soviet socialism and current capitalism have shaped 
human-environment relationships in Kyrgyzstan. Thus, the present forms of natural resource management can only be understood by taking historical stages and transformations into account. Furthermore, not only the role and function of natural entities have changed over time but often also the related societies. Starting with massive immigration processes of Russians and the sedentarisation of Kyrgyz nomads at the end of the nineteenth century, people have been settled and resettled in Central Asia in a constant flux until today (Hisao et al. 2000). Therefore, talking about local communities does not necessarily involve autochthonous societies with long traditions of close human-environment relationships but rather people with migration backgrounds who were socialised in other regional and social contexts. This paper explores the interrelationships between Kyrgyzstan's walnut-fruit forests and local societies as a consequence of the Tsarist and Soviet legacy as well as current globalisation processes. It asks how the walnut-fruit forests contribute to local livelihoodsand how the farmers have developed strategies for utilising their nearby natural environment. In this context, it is necessary to scrutinise changing institutional settings and forest management strategies as well as the dominating discourses shaping human-forest relationships.

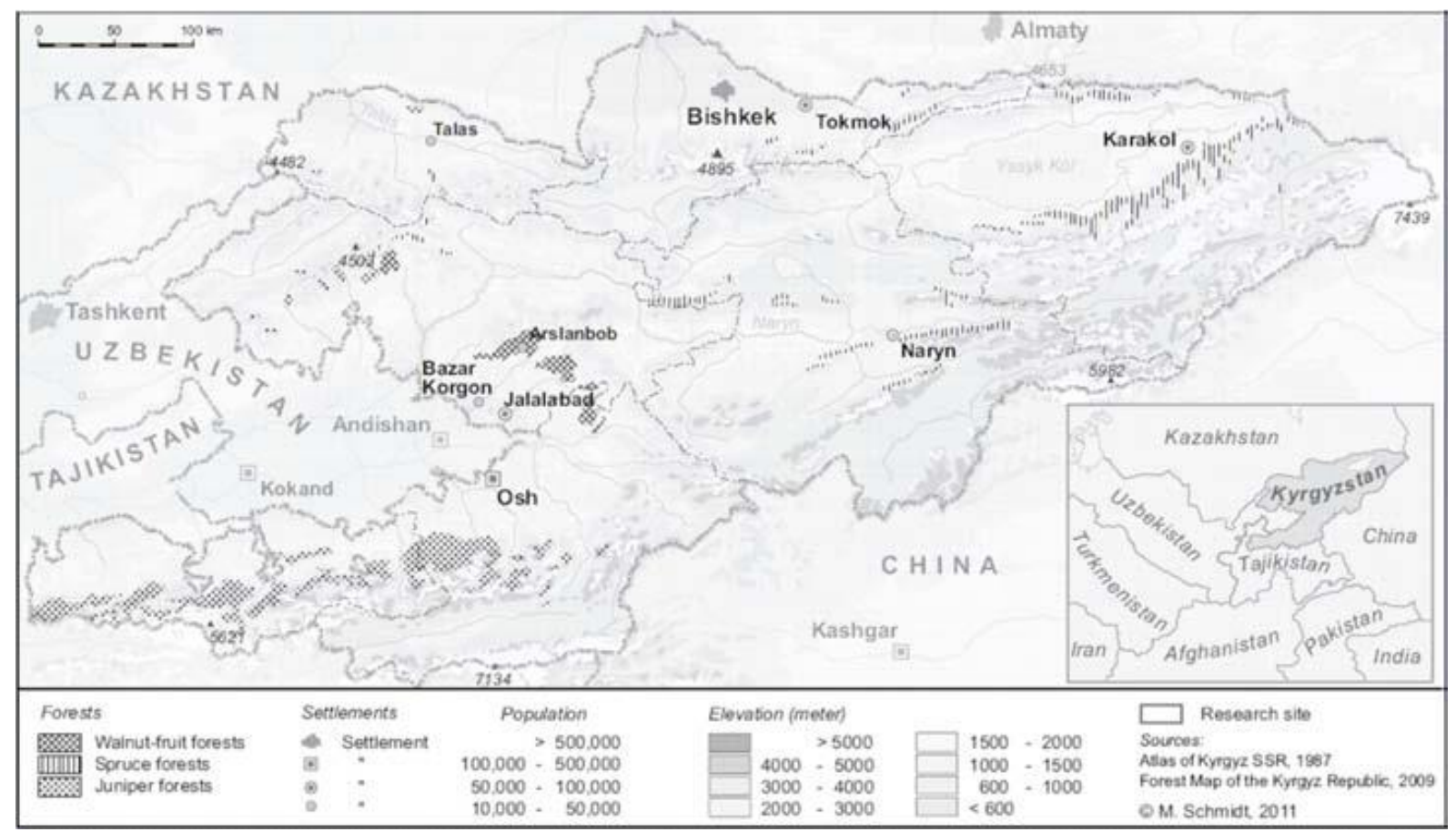

Figure 1. Location of contiguous forest stands in Kyrgyzstan.

\section{Theoretical background}

The interrelationships between political and socio-economic regimes, institutions of resource management and virtual resource utilisation stand in the centre of the paper. The three particular historic caesuras - the annexation of Central Asia by the Russian Empire in 1876, the October Revolution in 1917 and the dissolution of the Soviet Union in 1991 - and their related transitions of policy, economy and society have led to the restructuring and redefinition of governing institutions and property rights, to changing perceptions of nature and environment as well as to modifications of land and natural resource management. The research problem can be illustrated as a triangle of reciprocalrelationships (Figure 2).

Institutions legitimise and shape natural resource management; they govern access to resources and define how and by whom the available resource can be utilised. North (1991) defines institutions as 'humanly devised constraints that structure political, economic and social interaction' and 'consist of both informal constraints (sanctions, taboos, customs, traditions and codes of conduct) and formal 
rules (constitutions, laws and property rights)'. Following Sen (1981) and North (1991), institutions include both the rules of the game and organizations that create and control these rules. So, institutions sketch significantly the scope of action of the actors involved and the virtual resource utilisation, both of which are also influenced by economic needs and wishes. But the question which natural entity is to be considered as a resource is far from obvious and can differ in connection with political, social, economic or technical transitions.

The mountainous environment of the research area offers manifold microclimatic and geomorphologic conditions and thus a variety of ecological niches. Abiotic and biotic elements as well as localities become resources in their materiality and function only because of anthropogenic dedications. People assign them value, show interests and articulate demand for specific natural products, environmental services or territories. Resources are thus not material givens of nature per se, but should be seen as cultural esteems: 'Resources are not; they become' (Zimmermann 1933). As hybrid forms (socionatures) they are neither purely natural nor purely social. Specific natural entities can slip into or out of the category of resources, so resources have to be regarded as relational and as a dynamic category (Bridge 2009). This means that the appraisal of resources is irresolvably intertwined with social, political and economic factors. Economic liberalisation, facilitated access or intensified exchange relationships can lead to a transition of appraisal and interests in resources as well as to a change of the governing institutions and the field of actors. Following this argument, the changing socio-political conditions are seen as the main factor for transforming human-environment relationships in southern Kyrgyzstan.

In this context, not only the constructive character of natural resources but also of the environment becomes obvious (Escobar 1996). Although biophysical entities can be measured, analysed and classified in a positivistic way following methods and systems

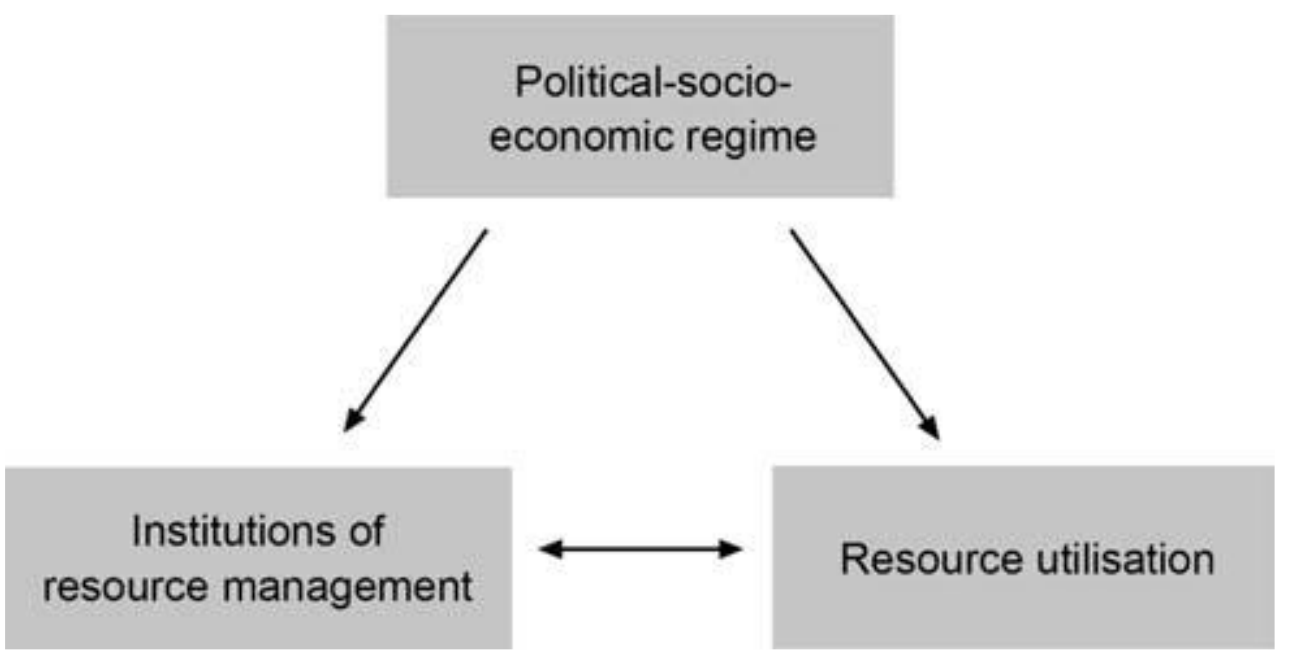

Figure 2. Interrelationships between political socio-economic regimes, institutions of resource management and resource utilisation.

established by dominating knowledge discourses (Haraway 1988), environment and natural elements mean something different to everyone in terms of subjective perception: a forest can be seen as an exploitable resource, as a refuge for specific fauna or flora, as a source of inspiration or as recreation space.

Hence, perception, knowledge and interpretation of natural areas and environmental elements, their human utilisation and material appropriation as well as regulations of access and management of resources (defined as such) are particularly shaped by political, social and economic processes and 
structures. Consequently, transformations of the environment are not only the result of direct interrelationships between humans and the environment on local levels but are also influenced by actions and decisions or structural conditions on other spatial levels. In this context, the group of actors includes both individuals and social groups that are directly confronted with the physical environment, the so-called place-based actors, and those who influence the actions of the former by demand or by the establishment and regulation of property rights, the so-called non-placebased actors (Blaikie \& Brookfield 1987).

Such a view of the environment corresponds with the research agenda of political ecology as a theoretical framework for analysing shifting dialectical relationships between social and power relations, local practices and ecological processes to allow a complex assessment of social and environmental change (Forsyth 2003; Robbins 2012). This approach stresses the political character of the environment and considers the multispatiality of agents, their interests and activities as well as the necessity for historical and ethnographic analysis in combination with a critique of existing economic frame conditions (Neumann 2005). Governing institutional arrangements, cultural practices and discourses about land use, resource management or environmental protection are focused, too. Using the political ecology approach will help to understand the changing human- forest relationships in Kyrgyzstan against the background of far-reaching political transformations.

\section{Research methods}

This study is based on extensive empirical fieldwork in Southern Kyrgyzstan since 2004. Information on historical and present forms of forest management and utilisation practices was gathered by quantitative and qualitative reconstructive forms of empirical social research, including a household survey, participatory observation and focused interviews. Around 800 households from four villages in the Djalalabad area (Gumkhana, Arslanbob, Kyzyl Unkur and Kara Alma) were surveyed with a standardised questionnaire to gain information on the economic situation and livelihoods of the households. The questions targeted the various forms of natural resource utilisation, agricultural and forestry practices, income-generating activities, holding of land, livestock and other properties, amount and kind of incomes and expenses, heating and the role of walnuts within local livelihoods. In addition, around 40 thematically focused interviews were carried out with various experts such as foresters, herders, members of the administration, craftsmen and others from the four investigated village communities. These interviews served to assess the changing role of the forests, the interests and concerns of particular stakeholders within the net of actors and the de jure and de facto governing institutions. In particular, forest management under Soviet rule was reconstructed from statements of people involved in forestry during this time.

In order to gain knowledge about the evolution of forestry and forest management from colonial times onwards, in particular concerning the Soviet era, numerous historical documents were analysed in archives and administrative institutions following the discourse analysis approach (Fairclough 1995) to explore and reveal the ways in which the forests were utilised, managed and discursively constructed.

\section{Changing human-forest relationships in Kyrgyzstan}

\section{Colonial land and forest seizure}

Prior to the annexation of the area by the Russian Empire in 1876, utilisation of the walnutfruit forests was limited to the autochthonous populations: nomads and sedentary communities cultivated fields, used the forests and grasslands as grazing grounds, collected fruits and produced charcoal, which was sold on the markets in the Fergana Valley (Lisnevski 1884; Korzhinskii 1896). The uniqueness of the 
forests and their multifarious functions and resources came into focus when, at the end of the nineteenth century, expeditions led by Russian explorers inventoried the potential natural resources of the Fergana region (Navrotski 1900). The walnut-fruit forests were highly esteemed mainly due to their ecological functions, in particular their positive impact on the hydrology of the region, which was seen as essential for the long-term functioning of the irrigation systems in the Fergana Valley, one of the major areas of cotton cultivation in Central Asia (Rauner 1901). Accordingly, the administration of the Governor-Generalship of Turkestan prohibited specific forest usages such as felling, charcoal production or extension of arable lands, and conceded to the local populations only the right to use grazing grounds according to their tradition (Svod zakonov Rossiiskoi Imperii 1892). However, the newly founded forest service noticed the occurrence and high value of walnut burls and assured itself economic profit: at the end of the nineteenth century already, a considerable number of walnut burls were being traded and exported to Marseille, France, where they were used for furniture production (Lesnoe delo v Turkestane 1902).

Apart from the above-mentioned ecological and economic interest in the forests, the Russian administration tried to gain political control of the territory and created administrative units. Forest farms were established and all forests were declared to be the property of the Russian Tsar (Svod zakonov Rossiiskoi Imperii 1892). With this colonial act, the autochthonous population was ousted from their traditional way of life: local people were not allowed to purchase land, to cut wood or to convert forest land into arable fields. Moreover, the ban on charcoal production resulted in the loss of additional incomes, whereas the limitation of pasturage rights resulted in a decline of winter fodder for their livestock. Capital yields were only realised by the Russian Government by selling walnut burls. It becomes obvious that the colonial administration enforced the Tsarist legal system by mainly ignoring local necessities.

During Russian colonial rule, the walnut-fruit forests were loaded with supra-local economic relevance: not only the direct exploration of particular resources such as walnut burls - which were promoted to a internationally traded commodity - but also the ecological services of the existing forests for erosion control to secure the irrigation systems in the Fergana Valley were of relevance for the colonial economy. For the local population, the forests served as an additional economic space for their subsistence or to generate income by the production of charcoal, but they came under pressure when their access and utilisation rights were limited in favour of the Russian colonial economy. On the one hand, the Tsarist administration laid the foundation for the economic utilisation of the walnut-fruit forests which is still practised today; on the other, they recognised the ecological significance of the forests at a very early stage and this has remained a kind of environmental meta-narrative up to the present day (Schmidt \& Dörre 2011). Without such an early prioritisation of forest protection, the forests would probably no longer exist.

\section{Planned forestry and human-environment alienation during the Soviet era}

During the Soviet era, the walnut-fruit forests kept their special status and were handled accordingly in a strict top-down approach: not only were the property rights held by the state, but also utilisation and protection measures were controlled and implemented by state agencies. To fulfil 5-year plans, local concerns were neglected and people were compelled to act as subordinates within the large Soviet experiment.

Nobody was asked what they wanted. The state dictated and regulated everything.

(A.Edelbekov, 19 April 2004) 
The collectivisation processes at the beginning of the 1930s marked a deep cut in the institutional frame: Kyrgyz nomads were forcibly settled and their livestock was expropriated; land and forests were declared public property and were managed by state farms (sovkhozes). Increasingly the various resources of the forests such as timber, nuts and fruits came into focus and were exploited systematically, in particular when the forests were placed under the control of Sojus Vitaminprom, the Soviet vitamin industry (Distanova 1974). The forced collectivisation and repression led to fear and alienation between population and governmental institutions, whereas the frequent institutional transformations prevented long-term forest management strategies and led to heedless exploitation of land and forest resources.

In 1945, the Council of People's Commissars declared the walnut-fruit forests to be State Fruit-Forest Reserves with specific regulations for protection and utilisation (Distanova 1974). The ecological relevancy of the forests was justified by their positive impact on the water cycle necessary for the irrigation systems and by the great species variety which could be used to select new hybrids for nut and fruit plantations elsewhere in the USSR (Gosudarstvennyi Komitet SSSR po lesu 1990-1991). A couple of years later, the walnut-fruit forests were subordinated to the Ministry of Forestry, and the sovkhozes concerned were transformed into state forest farms (leskhozes), which became responsible for carrying out all forestry measures at local levels.

According to the forest's status as State Fruit-Forest Reserves, the general aim of forest management was twofold: first, forest protection by implementation and control of strict regulations for logging and forestation; second, forest utilisation for economic purposes including the extraction of timber, firewood, nuts, apples and herbs, which were sold to other state enterprises. Local households obtained the right to cut grass on specific plots in the forest area to gain winter fodder for their livestock (Gosudarstvennyi Komitet SSSR po lesu 1990-1991).

Although wood harvest was officially strictly limited to the felling of dead or diseased wood only, major amounts of timber and firewood were cut yearly in all leskhozes of the area. As the development of timber and firewood harvest in the Leskhoz Kyzyl Unkur demonstrates (Figure 3), the amount of harvested wood could not be related exclusively to the availability of deadwood but was closely linked to local demands: with population of Leskhoz Kyzyl Unkur increasing from 834 in 1961 to 2360 in 1989 (Data from Natsional'nyi Statisticheskii Komitet Kyrgyzstan), the demand for timber and firewood also rose, and thus the amount of harvested wood too.

During the Soviet era, governmental forestry offered various employments for the local population; at least one person in each household was employed by the local leskhozes. The regularly paid salaries enabled local households to sustain their livelihoods. However, it is noteworthy that the local population cannot be equated with a somewhat autochthonous or indigenous population because only part of the local inhabitants originated in the area, whereas the majority consists of people from other regions. Over the course of time, not only Kyrgyz and Uzbeks from the Tian Shan Mountains or the Fergana Valley, but also Russians, Ukrainians, Tatars, Chechens and Germans from other Soviet Republics were settled in the area, resulting in multinational local communities (Schmidt \& Sagynbekova 2008). Closely embedded in the Soviet command economy, the local people were educated as specialised forest workers, carpenters or clerks to carry out forestry measures delegated by bureaucrats and party officials far away in lowland cities. In contrast to many other mountain communities, the villagers in the vicinity of Kyrgyzstan's nut forests cannot look back on a century-old tradition of forest utilisation or elaborate local knowledge. Instead, they were trained as employees of the leskhozes to exploit, or to protect, natural resources for the good of the Soviet system. Consequently, the ties between forest and people were not tightly knotted but only loosely bound. 
The relationship between forests and communities was kept aloof by the fact that nuts, apples and herbs were collected to be processed in other state units, whereas the consumption of these resources by the local population was prohibited. The leskhozniki did not even know where the walnuts were exported.

We delivered all collected nuts to the Leskhoz but did not know what happened with them later. (A. Mavlankulov, 6 March 2007)

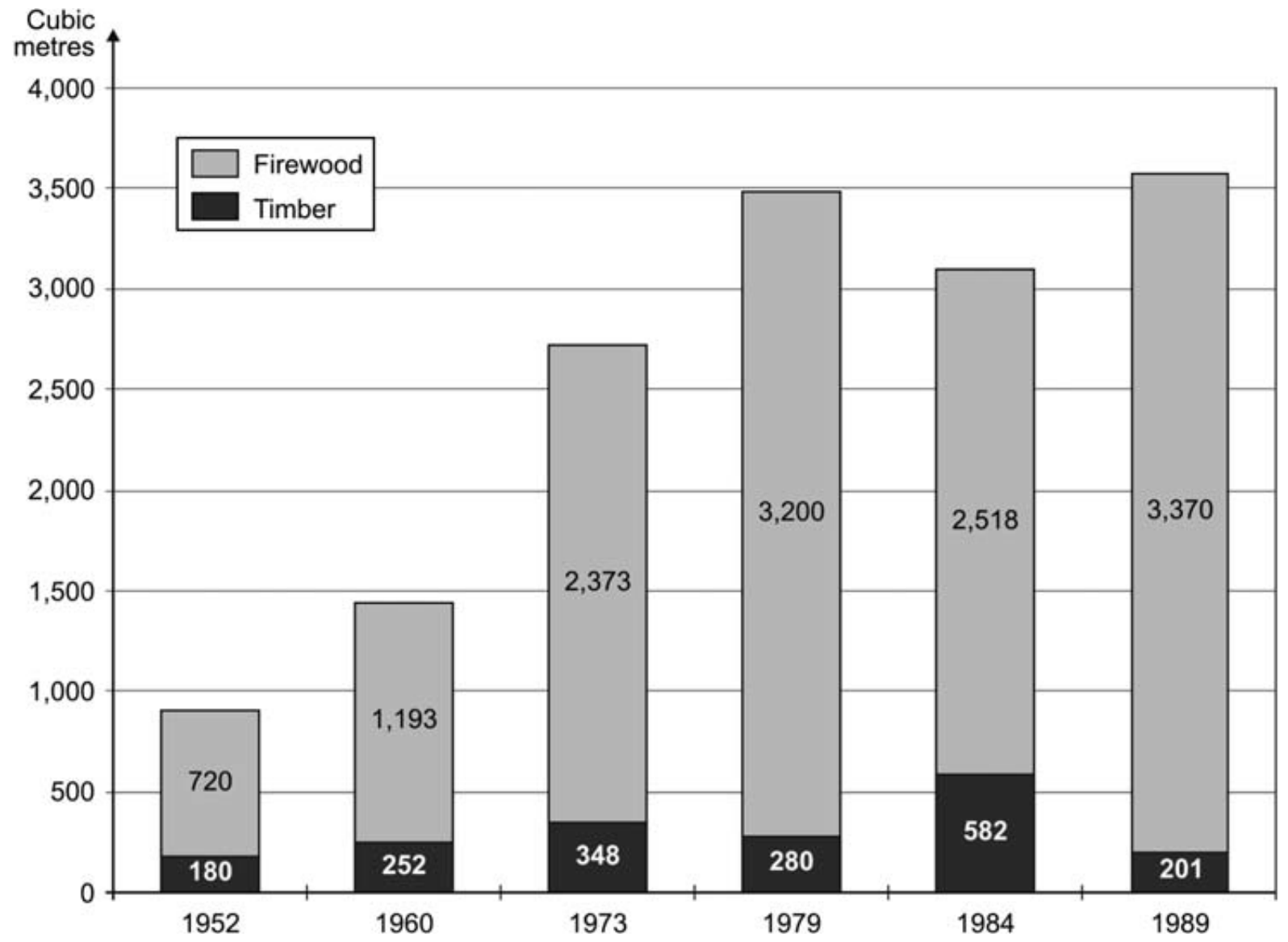

Figure 3. Timber and firewood harvest in Leskhoz Kyzyl Unkur (total forest area: 23,500 ha).

Sources: Annual reports by the Director of Leskhoz Kyzyl Unkur in 1952, 1960, 1973, 1979, 1984, 1989.

Good or bad yields only marginally influenced private incomes, so the well-being or productivity of the forests was not seen as paramount by the individual. The leskhozniki were not interested in collecting as many nuts as possible and left many unused, which at least supported a natural rejuvenation of the forests.

The labourers chose accessible and easy to harvest trees ( . . . ). Some nuts remained on the trees till the end of autumn and were not usable anymore with the onset of winter. (Distanova 1974, 51) 
The indifference concerning the success of the leskhozes was compounded by the latent but prevalent detachment between various groups within the society: the forced settlement and repression measures during the Stalin era, the prohibition of practising Islam, centralistic management and decision-making without consultation and participation of the local population all led to alienation between local populations and governmental institutions. Moreover, the fact that the local nomenklatura, the leading positions in the local administration, party organs and leskhozes were mainly filled with Slavs resulted in a feeling of inferiority on the part of ethnic Kyrgyz and Uzbeks. The social divide within local communities is also apparent when looking at the nonmaterial perception of the forests: parts of the Kyrgyz and Uzbek population also valued the forests for spiritual reasons. Several sacred places are located there, to which people from the region pilgrimaged to pray for healing of their ailments or for fulfilment of their desire for children. The party officials tried to stop such pilgrimages and saw these popular beliefs as a serious problem contradicting the atheistic Soviet ideology (Communist Party of Kirghizia 1962).

To sum up, the Soviet regime initially continued the Tsarist forest policy with slight modifications before the collectivisation deeply cut into existing structures. Political trials and tribulations, prosecutions and repressions and the necessities of the war economy during the Great Patriotic War resulted in institutional uncertainties and massive interventions in the forest stands. The establishment of the leskhozes went hand in hand with institutional consolidation, economic professionalisation and rationalisation. The conservation idea continued, while at the same time economic utilisation increased to offer the local population employment opportunities and to absorb - at least partly - high subsidies of the forestry sector by gaining revenues in other sectors such as beekeeping. As shown, national policies significantly influenced the management of natural resources and thus the immediate interrelationships between place-based actors and the environment. Obviously, decisions concerning forest resources in Kyrgyzstan were reached at national levels and implemented in command style; governmental forest institutions dominated political, cultural, social and economic life at the local level; the leskhozes evolved into 'total institutions' (Hann et al. 2002), rendering the local people indifferent to a sustainable forest management.

\section{Globalisation influences, institutional weakness and insecurity after 1991}

The dissolution of the Soviet Union and the independence of the Kyrgyz Republic in 1991, interlinked with tremendous economic and social ruptures, have brought about new fundamental changes in human-forest relationships. With the cutback of subsidies for the forestry sector, the elaborate but inefficient, less nature-sensitive and unsustainable Soviet system of forest management is eroding. Most people lost their formal employment and then had to develop new livelihood strategies in which the intensified utilisation of nearby land and forest resources plays a significant role (Fisher et al. 2004). According to the law, the walnut-fruit forests are still state property and managed by the local leskhozes, which are responsible for planning and implementing all forest activities, maintaining infrastructure, allocating lease agreements, issuing felling permits, etc. (Undeland 2011). But it is obvious that the leskhozes today are no longer able to manage and control their territories properly, so forest overutilisation is prevalent owing to pressing needs for firewood, fodder for livestock and income.

The value and function of the forests and the surrounding territories for local households can be seen by the fact that arable farming on small plots, animal husbandry and silviculture practices are carried out by almost all households in villages close to the forests in order to meet subsistence needs or generate income. Private flocks graze in the forests in spring and autumn, whereas livestock holders cut grass on the forest grounds at the end of the summer to gain winter fodder for their herds. Cattle and sheep are popular investments because livestock keeping is a profitable business and animals are flexible capital that can easily be transformed into cash when needed. As a result, the number of 
livestock in the village of Arslanbob quadrupled between 1979 and 2005 (Borchardt et al. 2010; see also Do"rre \& Borchardt 2012), threatening the existence of the walnut-fruit forests, because grazing livestock and intense mowing to gain winter fodder for the increased herds hinder natural rejuvenation and harm shrubs and small trees. Concerning non-timber forest products, the demand for nuts and fruits is no longer defined by the command economy, but follows market-based mechanisms. Within the frame of economic liberalisation in Kyrgyzstan (Pomfret 2006), mainly foreign businesspeople stepped in to run trading businesses. Walnut processing and trade are nowadays in the hands of mainly Turkish merchants, though they employ people from the nearby towns to open, sort and pack the collected nuts, which afterwards are exported to Turkey or the Gulf States (oral information by Turkish merchants of Bazar Korgon). Wild apples are today processed by a Chinese enterprise that opened in the nearby town of Jalalabad in 2002; the apple concentrate is exported to China. Morels that were collected only for private consumption in the past are nowadays highly esteemed by global demand. Some salesman export dried morels to France and Japan where they are sold as delicacies at high prices (Schmidt 2005). Furthermore, there is demand for various herbs of the forests; private merchants from the villages have specialised in this business and export the dried herbs to foreign countries. The local population uses these new opportunities to generate income by collecting and selling nuts, fruits, morels and herbs when possible. As shown in Table 1, almost all households are involved in collecting walnuts, whereas fruits are collected by around $89 \%$, morels by $64 \%$ and herbs by $52 \%$ of all households in the surveyed villages. Furthermore, since the delivery of coal and gas for heating and cooking purposes came to an end in the early 1990s, the collection of firewood is an imperative for all households which leads to a further thinning out of the already low-density and overmatured forest stands (Venglovsky et al. 2010). In particular, walnuts play an important role in the livelihood strategies of local households and are sold almost entirely to generate income (see also Undeland 2011). According to our survey, the income from nut selling contributes to the overall household income by an average of more than $23 \%$, but could be much higher in households without formal employment opportunities. Owing to this dependency, low nut harvests as a result of natural variabilities threaten household's livelihoods and can lead to impoverishment.

Table 1. Extraction of forest products from walnut-fruit forests by local households in Jalalabad

\begin{tabular}{lcccccc}
\hline Village & Timber & Firewood & Walnuts & Wild fruits & Morels & Herbs \\
\hline Arslanbob & 17 & 99 & 97 & 86 & 35 & 17 \\
Gumhana & 38 & 99 & 99 & 87 & 78 & 60 \\
Kara Alma & 44 & 100 & 100 & 97 & 67 & 58 \\
Kyzyl Unkur & 90 & 97 & 98 & 88 & 77 & 74 \\
Total & 47 & 99 & 99 & 89 & 64 & 52 \\
\hline
\end{tabular}

Source: Own survey 2004-2007. Sample size $(n=802)$.

Life in Kara Alma is very difficult this year because the villagers got only a small income from the walnut harvest. (Ajylshieva, 27 April 2004)

Apart from ecological factors, access to forest resources is crucial for people's welfare because the walnut-fruit forests are not an open-access resource. The focus on access highlights the mechanisms that enable and constrain the ability of groups to derive benefit from resources. Today, usufruct rights for harvesting are limited and a confusing legacy of the Soviet forest management system and halfhearted institutional reforms (Fiorino \& Ostergren 2012). All forests stand in state ownership and are 
officially managed by the leskhozes, but specific usufruct rights exist, which are mainly based only on vague permissions. For instance, the right to cut grass on specific plots given in the Soviet period still prevails, whereas the right to harvest nuts is given to local households on a yearly basis only. Quarrels and irregularities are common when usufruct rights for nut collection are allocated, especially in places with many inhabitants and limited forest resources. In the village of Arslanbob, for example, households were given no more than 8-10 walnut trees, which are not necessarily located on the plot on which the household has permission to cut grass. The nuts on a specific territory in the forest can thus be harvested by one household, whereas members of another household cut grass and others collect morels or apples; the leskhoz takes timber and firewood out of the same plot in the frame of sanitary fellings. The situation becomes even more confusing when stakeholders convert their rented forested plot into hay meadows or arable land (Messerli 2002).

Within the framework and support of the Kyrgyz-Swiss Forestry Support Programme, the Kyrgyz Government revised the forestry legislation (Temirbekov 2010) and introduced participatory approaches of forest management. In 1998, a pilot approach, the so-called collaborative forest management (CFM), was installed to transfer responsibilities to local stakeholders and to promote their involvement in forest management to achieve more sustainable forest utilisation and incomes for local households (Carter et al. 2003, 2010). According to the CFM lease system, local farmers were given forest plots with guaranteed property rights for a couple of years that could be extended to longterm leases. The tenants of these plots have the right to harvest, use and sell all forest products except timber, but have the responsibility for forest protection and maintenance (Carter et al. 2003; Schmidt 2007). Around 1000 CFM leases have been signed during the past decade, covering an area of more than 8300 ha (Carter et al. 2010), and thus promote forest governance by local households. However, this convincing idea came up against a forestry sector that finds it difficult to give up responsibilities, and in which corruption and nepotism prevail, so the distribution of plots to local farmers became a political issue in the respective villages. Similar to the existing system of forest lease, in which influential and better-off households could secure their utilisation rights at the most profitable forest plots, local decision-makers tended to favour their relatives and influential households in allocating access to these plots (Schmidt 2007).

Rich people easily get valuable plots. (Karimchanov, 17 August 2005)

In general, the lease of forest land and the permits issued to use forest resources, in particular walnuts, are the primary source of revenue for the leskhozes (Undeland 2011). In spite of various programmes such as CFM, there are sound endeavours to transform the forest-related institutions with the intention to reduce poverty and to support sustainable forest management. But a major constraint lies in the fact that long-established or recently introduced rules and regulations are often not accepted and institutions are often too weak due to the absence of sanctions and a lack of trust. Several organs such as municipal administration, state forest farms and councils of elders with specific competencies do exist formally, but the fairness, implementation and acceptance of rules by those concerned are questionable. This became particularly obvious with regard to the timber and burl business. Notwithstanding the existing felling ban, a large unofficial market of timber and burl wood flourished until a couple of years ago. In particular, foreign wood companies were interested in burl and root wood of nut trees, resulting in the felling of many old nut trees during the past 20 years. This valuable wood, which is used for exquisite veneers for items such as chessboards, gun butts or for the interiors of luxury cars, was exported to Western countries (Schmidt 2005). It seems that this business came to an end, partially not only because of stronger institutions but also because of the almost exhausted 
burl resources in the forests. Still some private enterprises of the region process timber that they mostly get via unofficial channels.

Apart from silviculture, the forest territories are also commodified as destinations for recreation. Scenery, fresh air and pleasant summer temperatures are valuable factors for tourism, which offers additional though only seasonal income for the local population. Several people provide accommodation, work as taxi drivers or sell local products to tourists from the region and increasingly from abroad. But the construction of resorts and the leisure activities of tourists stand in competition with forestry or conservation aims. A discourse analysis about the role, meaning and function of the walnut-fruit forests (Schmidt \& Do"rre 2011) shows that the idea of the forests' important ecological role is still a prevalent meta-narrative that is internalised not only by forest officials but also by the local population. The state forest service and local people feel responsible for protecting these forests, but their role is ambivalent because both either realise economic profits or sustain their livelihoods from the forests. The state declares reservation zones without having adequate means to implement the necessary measures. National and international scientists contribute to an accentuation of the environmental narrative by pointing out the uniqueness (Blaser et al. 1998) or even 'global significance' of these forests (Eastwood et al. 2009). Although not explicitly stated, a broader notion of the commodification of the forests is immanent in such statements: for instance, the necessity of safeguarding species diversity and especially genetic codes with a view to future economic utilisation of the material. Thus, scientists internationalise the nut forests by rating global interests higher than local concerns. Consequently, international scientists are demanding world natural heritage status for the forests and the creation of a nature preserve, and the Kyrgyz Government is proclaiming a 'natural park' by 2012 (State Agency on Environment Protection and Forestry under the Government of the Kyrgyz Republic 2010) - without consulting the local population. These notions demonstrate that concepts for forest protection did not arise from the understanding of an intrinsic value of nature, but instead were formed by powerful actors to create control systems over this natural resource. As shown above, the walnut-fruit forests offer valuable products and functions and contribute significantly to local livelihoods. But yields are too low or too insecure and the number of forest users is too high in relation to forest size (Jalilova \& Vacik 2012), the consequences being over-utilisation and the need for local households to obtain other non-forestry or non-agricultural incomes. The governmental sector offers employment only for a small portion of the community, so the vast majority of households send one or more family members abroad as labour migrants (Schmidt \& Sagynbekova 2008). Theoretically, the temporary or permanent migration of parts of the local community might reduce the pressure on the forest resources. At the moment, however, the opposite is happening because labour migrants often invest in the construction of houses or in livestock, thus increasing pressure on the forests.

\section{Discussion and conclusion}

As shown above, the human-environment relationships in Kyrgyzstan's walnut-fruit forests have changed significantly over the course of time and are closely linked to the socio-political context. Colonialism, socialism and capitalism implicate different forms of forest perception and management, making the forests a highly 'politicised environment' (Blaikie \& Brookfield 1987). The attribution of value and function of specific forest materialities or ecological processes is relational, following economic needs or political goals of global, national, local or individual relevance. So it becomes obvious that the walnut-fruit forests as repositories of natural resources and environmental services are a dynamic category and embedded in supra-local frame conditions and developments. The ecological significance and economic importance of the walnut-fruit forests were translated by the actors involved into institutions and management practices that should help to conserve the forests as well as to enhance economic utilisation. Since the beginning of formal forestry in the area, the attempt has been made to align the contrasting goals - exploitation and conservation - which were the guiding 
targets of establishing institutions and forestry measures. A great number of actors at various spatial levels are involved in human-forest relationships, whereas mainly non-local actors decide about institutional settings and forest management. After the Russian annexation, and in particular during the Soviet era, the local population was subordinated to superior plans and ideas, their individual concerns were mainly ignored and their activities controlled and limited. Undoubtedly, political and economic liberalisations since 1991 not only offer new chances and possibilities in particular for external actors but also bring new insecurities for local stakeholders which constrain sustainable forest management.

The value of the walnut-fruit forests is undoubted, and plans to establish protection zones have long existed, but were only realised on paper. Local people are aware of the high-forest biodiversity and the benefits they get from the forests, so they have a positive attitude towards conservation (Jalilova \& Vacik 2012). However, current economic difficulties and the necessity of the forest resources for local livelihoods result in a strong human impact on the forests and stand in sharp contrast to potential restrictive conservation measures.

The forest helps a lot. Income from the forests is very important. In times of lacking nuts or apples, life is very difficult. Apart from the forest there is nothing. There are only some arable fields and some livestock. All hopes are connected with the forest. (Kulmashova, 4 April 2004)

Currently, extensive pasturing, firewood extraction and selective timber cutting are threatening the existence of the forests; but because of the prevailing economic difficulties and limited alternatives for income generation, the local population must not be excluded from any conservation strategies. A higher added value within the area, for example the processing of nuts, fruits and timber, might be an important development measure and is not inconsistent with sustainable forest usage that must be accompanied by forestation to secure the very existence of these unique forests. Long-term leases for individual households are an important step forward. But a major obstacle to the development of a sound and widely accepted strategy of resource utilisation must be seen in the asymmetric power relations and in institutional weakness. Local inhabitants have no trust in official institutions in which corruption and nepotism prevail. The local leskhozes need to interact on a par with local governments and with the members of the local communities. However, all plans can only be successful if the existence of the various interests in the forests, the fields of actors at various spatial levels and the history of changing perceptions and appreciation are taken into consideration.

\section{References}

Adle C, Palat MK, Tabyshalieva A, editors. 2005. History of civilizations of Central Asia, Vol. VI: towards the contemporary period: from the mid-nineteenth to the end of the twentieth century. Paris: UNESCO.

Allworth E, ed. 1994. Central Asia: 130 years of Russian dominance: A historical overview. Durham: Duke University Press.

Beyeler S, Rehnus M, Venglovskaya GA, Sorg JP. 2011. Bibliography on the walnut-fruit forests of southern Kyrgyzstan. Zurich: Bishkek, Kyrgyzstan.

Blaikie P, Brookfield H. 1987. Land degradation and society. London: Methuen.

Blaser J, Carter J, Gilmour D, editors. 1998. Biodiversity and sustainable use of Kyrgyzstan's walnutfruit forests. Gland: IUCN. 
Borchardt P, Schmidt M, Schickhoff U. 2010. Vegetation patterns in Kyrgyzstan's walnut-fruit forests under the impact of changing forest use in post-Soviet transformation. Die Erde. 141(3):255-275.

Bridge G. 2009. Natural resources. In: Kitchin R, Thrift N, editors. International encyclopedia of human geography. Amsterdam: Elsevier; p. 261-268.

Carter J, Grisa E, Akenshaev R, Saparbaev N, Sieber P, Samyn J-M. 2010. Revisiting collaborative forest management in Kyrgyzstan: what happened to bottomup decision-making? Gatekeeper Series 108. London: Institute for Environment and Development.

Carter J, Steenhof B, Haldimann E, Akenshaev E. 2003. Collaborative forest management in Kyrgyzstan: moving from top-down to bottom-up decision-making. In: Gatekeeper Series 108. London: Institute for Environment and Development.

Communist Party of Kirghizia. 1962. About tasks to prevent pilgrimages to 'holy' sites at Bazar Korgon and Ala Buka rayons, 16 July 1962 [in Russian]. Jalalabad: Communist Party of Kirghizia.

Distanova V. 1974. History of Kirov Leskhoz of Lenin Rayon, Osh Oblast [in Russian] [Diploma thesis]. Frunze: Kyrgyz State University.

Dörre A, Borchardt P. 2012. Changing systems, changing effects - pasture utilization in the post- Soviet transition: case studies from southwestern Kyrgyzstan. Mountain Research and Development. 32(3):313-323.

Eastwood A, Lazkov G, Newton A. 2009. The red list of trees of Central Asia. Cambridge: Fauna \& Flora International.

Escobar A. 1996. Constructing nature: elements for a post-structural political ecology. In: Peet R, Watts $M$, editors. Liberation ecologies: environment, development, social movements. Routledge: London; p. 46-68.

Fairclough N. 1995. Critical discourse analysis. London: Longman.

Fiorino T, Ostergren D. 2012. Institutional instability and the challenges of protected area management in Russia. Society and Natural Resources. 25(2):191-202.

Fisher RJ, Schmidt K, Steenhof B, Akenshaev N. 2004. Poverty and forestry: a case study of Kyrgyzstan with reference to other countries in West and Central Asia. FAO Livelihood Support Programme. Working Paper 13. Rome: Food and Agriculture Organization.

Forsyth T. 2003. Critical political ecology: the politics of environmental science. London: Routledge.

Gosudarstvennyi Komitet SSSR po lesu. 1990-1991. Project on organization and development of forestry of Kirov Leskhoz [in Russian]. Kyrgyzstan's walnut-fruit forest 265

Gottschling H, Amatov I, Lazkov G. 2005. ZurO" kologie und Flora der Walnuss-Wildobst-Wa"Ider in Süd-Kirgisistan. Archiv fu" r Naturschutz und Landschaftsforschung. 44:85-130.

Hann C, Humphrey C, Verdery K. 2002. Einleitung: der Postsozialismus als Gegenstand ethnologischer Forschung. In: Hann C, editor. Postsozialismus: transformationsprozesse in Europa und Asien aus ethnologischer perspektive. Frankfurt: Campus. p. 11-48.

Haraway D. 1988. Situated knowledges: the science question in feminism and the privilege of partial perspective. Feminist Studies. 14(3):575-599.

Hisao K, Chika O, Schoeberlein JS, editors. 2000. Migration in Central Asia: its history and current problems. Osaka: The Japan Center for Area Studies.

Jalilova G, Vacik H. 2012. Local people's perceptions of forest biodiversity in the walnut fruit forests of Kyrgyzstan. International Journal of Biodiversity Science, Ecosystem Services and Management. $8(3): 204-216$. 
Korzhinskii S. 1896. Studies on plants in Turkestan. I - III. Zakaspiiskaia Region, Fergana and Alai [in Russian]. Saint Petersburg: Academy of Sciences.

Lesnoe delo v Turkestane. 1902. Report of the Director of Forest Department Turkestan 1900 [in Russian]. Lesnoi Journal. 6:431-472.

Lisnevski VI. 1884. The mountain forests of the Fergana region [in Russian]. Novyi Margelan.

Luong PJ, ed. 2004. The transformation of Central Asia: states and societies from Soviet rule to independence. Ithaca, NY: Cornell University Press.

Messerli S. 2002. Agroforestry: a way forward to the sustainable management of the walnut fruit forests in Kyrgyzstan. Schweizerische Zeitschrift fu“ r Forstwesen. 153(10):392-396.

Navrotski S. 1900. Statistical material on forestry of the Turkestan Region. Forest stations of Turkestan [in Russian]. Tashkent.

Neumann RP. 2005. Making political ecology. New York: Hodder Arnold. North D. 1991. Institutions. Journal of Economic Perspectives. 5:97-112.

Pomfret R. 2006. The Central Asian economies since independence. Princeton, NJ: Princeton University Press.

Rauner S. 1901. Turkestan's mountain forests and their impact on regional water management [in Russian]. Saint Petersburg: Academy of Sciences.

Robbins P. 2012. Political ecology: A critical introduction. Malden, MA: Wiley-Blackwell.

Schmidt K. 2007. Livelihoods and forest management in transition: knowledge and strategies of local people in the walnut-fruit forests of Kyrgyzstan. Reading: University of Reading.

Schmidt M. 2005. Utilisation and management changes in South Kyrgyzstan's mountain forests. Journal of Mountain Sciences. 2(2):91-104.

Schmidt M, Dörre A. 2011. Changing meanings of Kyrgyzstan's nut forests from colonial to post-Soviet times. Area. 43(3):288-296.

Schmidt M, Sagynbekova L. 2008. Past and present migration patterns in Kyrgyzstan. Central Asian Survey. 27(2):111-127.

Sen A. 1981. Poverty and famines: an essay on entitlement and deprivation. Oxford: Oxford Univeristy Press.

State Agency on Environment Protection and Forestry under the Government of the Kyrgyz Republic. 2010. Natsional'naya strategiya sokhraneniya biologicheskogo raznoobraziya Kyrgyzskoi Respubliki na 2011-2025. Available from: http://www.nature.kg/images/files/sr_bioraz.doc (accessed 12 October 2010).

Svod zakonov Rossiiskoi Imperii. 1892. Corpus Juris of the Russian Empire [in Russian]. Vol. 2. State of Turkestan's Administration.

Temirbekov A. 2010. Facilitating financing for sustainable forest management in small islands developing states and low forest cover countries. Country case study: the Kyrgyz Republic. Helsinki: Indufor.

Undeland A. 2011. Forest management and use in the Kyrgyz Republic: development potential. Program on Forests (PROFOR) and Rural Development Fund. Bishkek: World Bank.

Venglovsky BI, Mamadjanov D, Sorg JP, Rehnus M, Sarymsakov Z, Abdykakharov B. 2010 Bioecological bases for forestry management in walnut forests of Kyrgyzstan and their multifunctional use. Bishkek: National Academy of Sciences Kyrgyzstan. 
Zimmermann E. 1933. World resources and industries. New York: Harper Row. 